\title{
COMPARATISMO: PARA UM REAJUSTE DA GEOGRAFIA DA LITERATURA
}

\author{
Biagio D'Angelo*
}

RESUMEN: este trabajo pretende releer el concepto de comparatismo a partir del desarrollo siempre más creciente de intereses hacia proyectos e investigaciones sobre las literaturas post-coloniales. La literatura comparada, por largo período, se centralizó, justamente, en la diferencia lingüística de producciones culturales y literarias. En nuestros días, con la intención de preservar las diversas lenguas, como proyecciones o como generadoras de diversas culturas que componen el mosaico de la phoné monolingüística del pasado (francofonía, anglofonía, lusofonía etc.), resulta estimulante la perspectiva de conjunto de ciertas literaturas, reconocidas por largo tiempo como periféricas, las cuales, en la multiplicidad de los espacios y de los discursos lingüístico-culturales, se aproximan las unas a las otras, por medio de un único eje (una mono-lengua dominante) que, contextualizada, ha generado las historias, las culturas, las lenguas, las efabulaciones de diversos lugares.

\section{PALAVRAS-CLAVE: literatura comparada, literaturas post-coloniales, lusofonía, Mia Couto, Guimarães Rosa} \footnotetext{
brilhar no coração das pessoas (José Eduardo Agualusa).

A língua é minha pátria e eu não tenho pátria: tenho mátria e quero frátria (Caetano Veloso, "Língua”).
}

Em uma ocasião perguntaram ao grande jornalista e escritor polaco Ryszard Kapuscinski o que mais impressionara nas suas viagens à África, ele, que havia viajado pelo mundo inteiro. Sabe o que respondeu? A luz! Eu acho que Kapuscinski tem razão, e acho que essa luz contamina as pessoas, transforma as pessoas, acho que olhando bem, olhando bem de perto, você vê essa luz

Existe, por acaso, um arquivo da língua inglesa, nova língua franca dessa nova "romanidade" pós-colonial, ou da francesa, dominadora por secula seculorum de départements d'outremer, como criaram os brasileiros, recentemente, com o Museu da Língua Portuguesa em São Paulo? De onde flui a origem do desejo de preservação das impressões que deixa a língua como armazenamento cultural? Talvez um gosto e um pressentimento de morte e da desaparição de marcas e escritas, talvez o gosto macabro

*Professor da Pázmány Péter Katolikus Egyetem (PPKT - Hungria). 
de ver-se eternizado como povo/povos, sujeito/comunidade, como uma múmia no British Museum de Londres. A ideia de consignar a um lugar específico, como o é um museu, a memória de uma língua colonial que ultrapassou mares e fronteiras geopolíticas para preservar o mais frágil da comunicação humana, a fala, e com ela, o discurso cultural que dela provém, deve-se a uma conscientização do perigo, típico do contexto geopolítico e cultural contemporâneo, de se perceber como esquecimento, censura e repressão. A criação de um museu representa um ato de afeição à própria história e tradição e um lugar de convocação dos signos culturais, "congelados", por assim dizer, pela marca do lugar que se move entre técnicas de repetição e novos clientes.

Desde a origem, uma pulsão necessária ao sujeito é custodiar e interpretar os arquivos da memória (cultural, em primeiro lugar): se o museu serve como armazém e permanência de signos como línguas, culturas e modos, ele se completa só na relação que o "cliente" mantém com ele: assim, lembrando, memorizando e registrando tudo, para que nada seja perdido e, enfim, fechar, arquivar no museu os pontos de contato com a história pessoal e da comunidade em que o sujeito se move, aspira e vivencia.

Todavia, forças de poderes misteriosos, que alguns definem como "hegemônicos", percebem a língua como um bem transitório, perecível, destinado a se aglutinar em um unicum generalista e apagador das diferenças. Eliminando, dessa forma, a memória em uma amnésia provocada como desarraigamento da verdade, surge como resposta inelutável aos processos de esquecimento das diversidades. Como a experiência da memória não resulta espontânea, e essa memória pode perder território, Derrida escreve, em Mal de Archivo, que "o arquivo tem lugar no lugar do desfalecimento originário e estrutural dessa memória” (DERRIDA, 1997, p. 19 tradução minha).

A instituição de um Museu da Língua Portuguesa, que aqui se recorda, preserva o que é um dever do cidadão e, ao mesmo tempo, o direito de cada sujeito que quer discutir e vivenciar questões de identidade nesse começo de milênio. Como todo museu, esse Museu é, conforme as palavras de Derrida,

[...] revolucionário e tradicional. Arquivo eco-nômico neste duplo sentido: conserva, põe em reserva, poupa, mas de um modo não natural, isto é, fazendo a lei (nomos) ou fazendo respeitar a lei. O chamávamos [...] nomológico. Tem a força da lei, de uma lei que é a da casa (oikos), da casa como lugar, domicílio, família, linhagem ou instituição (1997, p. 21).

O desenvolvimento sempre crescente de interesses por projetos e pesquisas sobre as literaturas pós-coloniais pretende preservar as diversas línguas como projeções ou como geradoras de diversas culturas que compõem o mosaico da phoné monolinguística de um tempo (francofonia, anglofonia, hispanofonia, lusofonia etc.). É assim que resulta nova a perspectiva de conjunto de certas literaturas, reconhecidas por largo tempo como periféricas, as quais, na multiplicidade dos espaços e dos discursos linguístico-culturais, aproximam umas às outras por meio de um único eixo (uma monolíngua dominante) que, contextualizado, tem gerado as histórias, as culturas, as línguas e as efabulações de diversos lugares. Se pensarmos em "lusofonia", tratar-se-ia de Portugal, Brasil, África (Angola, Moçambique, Cabo Verde, Guiné-Bissau e São Tomé e Príncipe) e Oriente (Timor, Macau e Goa).

Com o surgimento dos estudos dedicados às literaturas e culturas pós-coloniais, 
a teoria e a prática da proposta comparatista têm sofrido importantes alterações, causadas pela necessidade de poder interpretar e conhecer, mais de perto, as resultantes dos processos históricos das várias colonizações dentro dos diferentes países e seus fenômenos político-culturais atuais. Se pensarmos, por exemplo, nas literaturas de língua portuguesa, produzidas em vários continentes, a visão anterior da literatura comparada de trabalhar exclusivamente com modelos pertencentes a campos culturais e linguísticos diferentes resulta, hoje, ser discutível e se transforma em uma perspectiva nova e fascinante. De fato, ao prestar particular atenção à discussão sobre o âmbito e o alcance da noção de "lusofonia", estas diversas literaturas e culturas manifestam uma extraordinária heterogeneidade, por causa das diferenças linguísticas que a língua portuguesa vem revelando no contato com os variáveis espaços geográficos. As relações histórico-culturais, aliás, contribuíram para diversificar espaços fabulatórios e ficcionais cuja consciência estética ainda não resulta ser muito (re)conhecida.

A articulação do espaço lusófono produziu um diálogo intercultural que não tem precedentes, nem mesmo na literatura de marca inglesa pós-colonial. Evidências míticas e folclóricas e divergências estéticas de uma lusofonia artística "vibrante de cultura" (AGUALUSA, 2007, p. 5) estão enriquecendo uma literatura que se quer tendencial, mundial e que está vitalizando os estudos de literatura comparada.

Sendo o estudo das áreas literárias e culturais da lusofonia um espaço discursivo ainda relativamente jovem, as questões levantadas pelas análises pós-coloniais (em particular, as problemáticas de identidade e alteridade) correspondem, com pleno direito, às necessidades da literatura comparada como disciplina que indaga regiões fronteiriças que aspiram a um trânsito e a um reconhecimento universal. As fronteiras culturais que os países lusófonos defendem aspiram a uma centralização canônica, a uma superação das margens e a uma defesa da própria entidade nacional e regional como "particular" de uma literatura-mundo.

A representação da identidade e da alteridade nas obras literárias de autores lusófonos resulta fortemente vinculada com as figurações de personagens, lugares, mitos (do contexto local ou importadas de outras culturas) que privilegiam o diálogo entre colônia e espaço geopolítico. Essa representação ficcional, que revela autores de grande impacto estético e ideológico, como Mia Couto, Pepetela, Luandino Vieira e José Eduardo Agualusa, manifesta-se principalmente em dois eixos que queremos discutir. O primeiro fundamenta-se na construção de um imaginário específico, no qual os signos do mundo exterior e os fenômenos psíquico-físicos oscilam entre a experiência do eu e o predomínio, ainda poderoso, de uma coletividade vista sob o ponto de vista social e "poético", transmissora de mitos. O segundo, através da reescrita (por exemplo, da história) resgata discursos de natureza heterogênea para outorgar força e originalidade ao imaginário da fábula: o épico, o mítico e o religioso se misturam aos re-pensamentos daqueles elementos históricos, como as guerras e as reconfigurações geográficas, que resultam incompreensíveis e dos quais só a literatura pode vislumbrar certa "saída".

Esses eixos nunca resultam paralelos e nunca se cruzam em pontos determinados e previsíveis mas, envolvendo-se em um movimento sinusoidal agregativo, formam os componentes da tipologia da escrita lusófona. A interação dos elementos orais e escritos revela processos originais retóricos e poéticos em que a repetição, a transformação, a paródia ou a contemporização das imagens e dos mitos propostos são metamorfoseados para a formação da consciência estética, ideológica e coletiva, ou para o reconhecimento 
do outro como raça, diversidade linguística e alteridade ontológica. Trata-se de configurações supranacionais que a literatura comparada, superando o antigo esquema de um binarismo linguístico (estudar as literaturas de dois ou três países de idiomas diferentes) assume como relevantes no incremento das significações da disciplina.

Se nós queremos realmente, retomando as palavras de Cláudio Guillén, uma literatura comparada "una e múltipla", criar-se-ia um espaço "ibero-afro-americano" que Benjamin Abdala define, por meio de um termo utopista, de "comunitarismo", onde as fronteiras colaboram para reinventar o mapa da comparada e sua bacia cultural lusófona: "são fronteiras estas - que envolvem a antiga metrópole e sua ex-colônia não de separação, mas de colaboração, onde desempenha papel ativo a formação cultural (comunitarismo cultural) que se estabeleceu entre o novo e o antigo centro" (ABDALA, 2003, p. 87).

O espaço que gera a perspectiva comparatista consiste em deixar perceber a multiplicidade das diferentes culturas e línguas dentro de uma língua da origem, quase mítica e instigadora de significantes. Embora seja só uma, a língua (a "-fonia” do português) recupera-se nas explorações de suas variantes. Ela reformula um mapa polimorfo, híbrido, cujo conteúdo é a produção de sentido simbólico de "identidades em diferença", como sugere Laura Cavalcante Padilha: "somos todos, os ex-cêntricos, viajantes em uma língua que se arriscou a lançar suas âncoras em outros e distantes portos" (PADILHA, 2005, p. 87). Trata-se de uma língua que funciona como experiência aglutinante, uma "língua de viagem", como diria Manuel Rui Monteiro, uma língua de existência.

Em vários autores, essa "fonia", essa língua comum, feita de "origem", de dimensões míticas e pluralidades culturais que a diferenciam, manifesta-se como poética afirmada e reconhecida por meio da produção de um "ex-cêntrico", de um autor que elevou a língua portuguesa (não portuguesa) à dignidade de língua planetária: Guimarães Rosa. A língua misturada de Guimarães Rosa constitui-se como a fonte secundária, após a conscientização da própria língua e cultura, para perceber o regionalismo, o periférico, o esquecido (sejam eles sertão, caatinga ou vilarejos angolanos) como um espaço poetizável, um espaço de comunidades textuais (não imaginárias, mas vivenciadas), um espaço em que a literatura, como experiência do global e do marginal, estabelece uma rede complexa de relações supranacionais (que envolvem, em um mesmo terreno discursivo, simbolizações políticas e míticas) em busca de uma tradição.

A literatura alimenta-se da força intertextual que provém das produções das comunidades. A migração de conceitos, alegorias, poéticas, repetições e divergências culturais representa, de fato, o enriquecimento e o processo vivo da configuração do fazer literário. Para René Wellek, esse intercâmbio, que se repercute de literatura a literatura, representa o objeto central da proposta da literatura comparada porque, nessa incansável multiplicação de significações poéticas, combate-se "o falso isolamento das histórias literárias nacionais" (WELLEK, [s.d.], p. 244).

As comunidades interliterárias não podem existir nem se desenvolver isoladamente sem a superação das fronteiras nacionais e as variações geradas pela integração de outros contextos:

A constituição dessas comunidades interliterárias é de natureza múltipla, condicionada por fatores variados, que podem ser geográficos, políticos, linguísticos, de proximidade de parentesco ou mesmo de analogia de 
procedimentos artísticos [...] Por isso, cada literatura nacional pode tornar-se, ao longo de seu desenvolvimento histórico, um componente de várias comunidades interliterárias, não se constituindo essas em sistemas fechados ou invariáveis. Essa proposta teórica nos permite reavaliar noções como a da literatura nacional, examinando-a em suas articulações com outras literaturas (CARVALHAL, 2003, p. 84-85) ${ }^{1}$.

Entender a lusofonia como um mapeamento e uma reformulação das relações que compõem as produções literárias pode ser considerada como uma nova tarefa do comparatista e do teórico da literatura. Nessa aproximação torna-se necessário, como afirma Tania Franco Carvalhal, "redefinir seus campos de atuação e de acentuar, em sua prática, a compreensão da literatura como um todo" (CARVALHAL, 2003, p. 86). As perspectivas pós-coloniais recebem assim uma abertura ao diálogo e ao reconhecimento comunitário, acentuando "a generalização em detrimento da simples comparação entre elementos e a ampliar os seus domínios em uma perspectiva interdiscursiva e interdisciplinar" (CARVALHAL, 2003, p. 87).

Nesse sentido, além da tradição histórico-regional que cada país propõe como bagagem e fardo do passado, pode-se dizer que Guimarães Rosa atua como ponto de referência reconhecido de uma estética de fragmentos, mortes e esperanças, de provérbios, citações e recordações pessoais onde a escritura é o caminho do não esquecimento e, ao mesmo tempo, da denúncia nítida do "esquecimento" do mundo. $\mathrm{O}$ "apoio" no paradigma criativo rosiano corrobora a intuição de Pires Laranjeira que sustenta a atualidade, nas letras lusófonas, de uma "liquidação (ao repensar literário) dos antigos mitos, sonhos, realidades e utopias, estando a escrever-se, na narrativa, um novo capítulo da história [literária]" (PIRES LARANJEIRA, 2001, p. 193). Obras literárias da África lusófona como $O$ último voo do flamingo, Luuanda ou $A$ varanda do frangipani entrelaçam um diálogo dramático com os recursos do passado históricomítico, misturando o desconforto pelo mundo presente com a perplexidade e a incerteza do futuro, de que as ficções se fazem porta-voz. "Resta saber", conclui Pires Laranjeira,

[...] face às contingências e solicitações da instituição literária, na contemporaneidade pós-colonial, se as literaturas africanas se deslumbrarão com a sociedade do espetáculo ou se hão de inscrever na continuidade de um casticismo intemporal, tendo a capacidade de engendrar e de expressar novas utopias e esclarecimentos" (PIRES LARANJEIRA, 2001, p. 193).

Mia Couto e Luandino Vieira, cada um a partir do próprio lugar de enunciação e escrita (moçambicano, para o primeiro e, como é notório, angolano para o segundo), têm sido, ao lado de outros já mencionados, os paradigmas culturais desta estética plural que anseia ser aceita em uma proposta universal. Não é um caso que para eles o escritor tem que relatar estórias, como sugeria o modelo de Guimarães Rosa. Também não faltam surpreendentes proximidades biográficas entre, por exemplo, o autor de Grande sertão: veredas e Mia Couto: ambos cientistas (médico um, biólogo o outro), curiosos viajantes e etnógrafos, se encarregam de reinventar histórias ouvidas nas ruas dos vilarejos ou nos mercados, onde, conforme um gosto performático, ainda público, como nos espetáculos de praça da Idade Média, importa não apenas a trama, mas a

\footnotetext{
${ }^{1}$ Tania Carvalhal já havia analisado esses conceitos também em outro artigo, intitulado "Comunidades interliterárias e relações entre literaturas de fronteira". In: ANTELO, Raúl (org.). Identidade $e$ representação. Florianópolis: UFSC, 1994. p. 93-102.
} 
modalidade com a qual a estória é contada: um provérbio ou um ditado podem ser relatados para fins didáticos; uma parábola pode servir de alegoria; o imaginário mítico pode, saindo das trilhas de uma literatura estagnada e sem brilho, reconstituir um novo "fantástico", segundo a acepção famosa que lhe outorga Todorov: uma "hesitação experimentada por um ser que só conhece as leis naturais, face a um acontecimento aparentemente sobrenatural" (TODOROV, 2004, p. 31). Na "incerteza" de ver espíritos ou ouvir os pangolins profetizarem, o fantástico define, portanto, as relações de real e fictício no imaginário da lusofonia. Apresentando-se como "estratégia de enfrentamento do real", como propõe Inocência Mata, trata-se de uma narrativa que prefere o insólito, o absurdo (ou o que parece tal): "assim, pela recorrência a um determinado léxico que aponta para o sonho, o sono, o ar, a água, esgarçam-se as fronteiras do dito e do estatuído e a atmosfera da inventividade alarga as margens da imaginação" (MATA, 2003, p. 68). O fantástico aproxima, de forma extraordinária, a África de língua portuguesa com a produção da literatura latino-americana do século $\mathrm{XX}$, na qual Guimarães Rosa, novamente, assim como Cortázar, resultam ser os "ancestrais" dessa efabulação.

Nesse obsessivo processo de recriação verbal e cultural, como bem sintetiza Pires Laranjeira, diferentes discursos interferem para reformular e nomear um sertão africano, revelador de cosmogonias inimagináveis e de proximidades à desconstrução linguística proposta por Rosa:

A criação de uma linguagem literária tocada pela oralidade, a combinação da sintaxe circunloquial com a tendência para a elisão e o sintetismo, a propensão luxuriante do neologismo, da aglutinação, da prefixação e outros modos de retrabalhar o léxico, em um processo de escrita que simula a ingenuidade e a singeleza, mas ostenta as marcas do impiedoso buril. Trata-se de um estilo que repõe a graça e o carinho da palavra que procura desvelar o mundo encoberto da essencialidade cósmica, manifestando compreensão e ternura pelos seres e coisas fustigados pelos ventos da história. A enumeração dos resultados da criatividade lexical seria impensável, mas convém fornecer alguns exemplos, para dela se poder aquilatar: homenzarrou, depressou-se, fantasiática, carinhenta, esteirados, rebulir, estremungado, tropousar, manifestivo, estremexendo, nuventanias, febrilhante, deslembrara, sozinhidão, perturbabado, gesticalada, irmãodade, exuberrante, inutensílio, tintintilar, entrequando, esmãozinhado, exactamesmo, convidançante, mancha-prazeres, embriagordo, veementindo, atordoído, titupiante, inaposento, administraidor etc. A sintaxe apresenta-se também como urna construção em moldes inusuais, entre a oralidade e a pura invenção, em que o contexto comunicativo, estético, permite partilhar a mensagem de ruptura: "todos partiram, um após nenhum"; "o colar que foste dada"; "nem isto guerra nenhuma não é”; "parece está aqui enquanto nem"; "o lugarzinho no enquanto” (PIRES LARANJEIRA, 2001, p. 200-201).

Desse trecho resulta ainda mais evidente a influência, decisiva e abertamente declarada, da poética rosiana: a linguagem se renova e se recria por meio de neologismos e deformações sintáticas que provém da marca da oralidade e funcionam como redescobertas da língua originária, perdida no desgasto quotidiano e no sentido etimológico. É uma revitalização que decorre das inter-relações com os mitos e as lendas do povo africano, como o mito do wamulambo em A varanda de frangipani. Como em Guimarães Rosa, para Mia Couto e Luandino Vieira, a língua não representa apenas um processo de renovação estetizante, mas coincide com a necessidade de dar 
espaço e voz a realidades marginais, silenciadas anteriormente, que procuram um reconhecimento central. Luandino Vieira declara a fulguração intelectual que ele flagrou em Sagarana:

Eu já sentia que era necessário aproveitar literariamente o instrumento falado dos personagens, que eram aqueles que eu conhecia, que me interessavam, que refletiam - no meu ponto de vista - os verdadeiros personagens a pôr na literatura angolana. Eu só não tinha ainda encontrado era o caminho. [...] Eu só não tinha percebido ainda, e foi isso que João Guimarães Rosa me ensinou, é que um escritor tem a liberdade de criar uma linguagem que não seja a que os seus personagens utilizam: um homólogo desses personagens, dessa linguagem deles (LABAN, 1980, p. 27).

Assim, memória, signos culturais, contextos políticos, modelos míticos e ancestrais são desvendados em uma dupla contextura, tecida pela subversão das palavras e pela narratividade que inquietamente recompõe (e interroga) a História por meio de estórias.

Para Mia Couto e Luandino Vieira, essa subversão passa e se reflete no poder que a palavra possui, um "poder de palavra" que "é sempre uma palavra de poder". (HANSEN, 2000, p. 62). Eles emaranham, em um processo de (re)semantização da linguagem e de (re)significação do fazer literário, o cotidiano e o insólito, ou melhor, o cotidiano vivenciado naquilo que resultaria insólito aos padrões da lógica cartesiana ocidental. Os cânones da racionalidade são subvertidos e a escrita deixa espaço a um imaginário fantástico que é uma alegoria - estética e ideológica - da crítica da realidade e de suas ambiguidades e erros históricos. Longe de ser um fantástico ingênuo ou meramente fabulístico, a proposta narrativa desses autores transgride a linearidade dos eventos da história oficial e contamina o real de auras e crenças mítico-supersticiosas que revelam uma realidade mais rica, mais significativa e provocante, em definitiva, uma mais realidade.

Curioso, portanto, resulta a escolha dos autores africanos em misturar as práticas da oralidade (do povo, da comunidade) com o discurso da ideologia (do artista, de sua leitura do mundo) e, ao mesmo tempo, a orientação privilegiada pela forma do provérbio, ruína (no sentido benjaminiano) dos processos da oralidade e da narratividade primigênia. Em algumas páginas penetrantes sobre Tutaméia, autêntico compêndio de provérbios e ditos aforismáticos, Luiz Costa Lima bem ilumina sobre a razão da necessidade e da prioridade dessa "forma simples" fragmentada:

O provérbio é índice de um tempo, abolido com as condições que favoreceram o advento do romance. [...] O provérbio encarna a parte de uma cosmovisão, que, entretanto, não saberíamos reconstituir, pois, ao contrário do que sucede com a narração mítica, sua propagação nos impede de conhecer o contexto primitivo de que derivou (LIMA, 1974, p. 16).

Ainda dentro da recepção do universo rosiano, a proposta de Mia Couto e de Luandino tenta reconstruir, por meio da escrita, a fala de uma comunidade, da qual se incumbe o narrador, figura-ponte, profeta e intérprete ideal, e, sobretudo, xamã das palavras e das poéticas recônditas que precisam ser divulgadas e mantidas na marca permanente da escrita. A tradição é perpetuada graças à preferência pela brevidade do provérbio que poetiza o real, afirma as histórias singulares e comunitárias e representa 
aquele "elo que reúne o contingente, o destino individual e o território das perguntas irrespondíveis" (LIMA, 1974, p. 20). O provérbio, se configurando, portanto, como ligação entre o passado quase atemporal e um presente histórico, cuja arquitetura se realiza por meio da ficção literária, se estabelece como vínculo de continuidade com o futuro, oscilando entre utopias e desesperos: "e os traços da oralidade presentes [...] funcionam, não como cacos de um passado irremediavelmente perdido, mas como sementes de um porvir que se constrói no presente" (MARQUEZINI, 2006, p. 60).

São inúmeros os exemplos de ambos autores nesse sentido. Contudo, gostaria de dedicar essa parte conclusiva do meu exposto às três narrativas contidas em Luuanda e a duas obras de Mia Couto indicativas da busca de um imaginário africano prometedor de novas efabulações: A varanda do frangipani e Terra sonâmbula.

"Minha estória. Se é bonita, se é feia, vocês é que sabem. Eu só juro que não falei mentira e estes casos se passaram nesta nossa terra de Luanda". É a conclusão de Luuanda. O juízo estético que Luandino Vieira exige do leitor-ouvidor das três estórias combina-se com a concepção utópica de a literatura marcar as etapas de uma nova consciência nacional e histórica, e de se incluir em um anseio universal de pedido por um espaço reconhecido. Mais uma vez, como em Guimarães Rosa, fazer uso da tradição significa, em Luandino, uma releitura do contexto histórico e das possibilidades ainda inexploradas da linguagem.

"Vavó Xíxi e seu neto Zeca Santos", a primeira estória do livro, é um exemplo comovente, cujos personagens, fracassados e desesperados, acham conforto em lágrimas libertadoras. Chorando, Zeca recobra sua verdadeira força existencial e reformula o orgulho africano de auto-suficiência. Como se pode ler nas últimas páginas, a atitude de Zeca abre espaço à metáfora de uma purificação que inunda todo o relato:

Com um peso grande a agarrar-lhe o coração, uma tristeza que enchia todo o corpo e esses barulhos da vida lá fora faziam mais grande, Zeca voltou dentro e dobrou as calças muito bem, para aguentar os vincos. Depois, nada mais que ele podia fazer já, encostou a cabeça no ombro baixo de vavó Xíxi Hengele e desatou a chorar um choro de grandes soluços. Parecia era monandengue, a chorar lágrimas compridas e quentes que começaram a correr nos riscos teimosos as fomes já tinham posto na cara dele, de criança ainda (VIEIRA, 2006, p. 43).

A solidão de Zeca Santos é vencida pela solidariedade de três africanos na prisão - Xico Futa, Lomelino dos Reis e Garrido Fernandes, na narrativa central, "Estória do ladrão e do papagaio". O surgimento da amizade entre eles representa uma espécie de comunhão mítica, na qual reafirma-se que, para viver dignamente, é indispensável ter consciência da "raiz" (palavra que ocorre repetidamente), isto é, do primum mobilis que move os desejos e esperanças dos sujeitos. Na parábola didático-moralista do cajueiro, Xico Futa declara com certeza:

O fio da vida não foi partido. Mais ainda: se querem outra vez voltar no fundo da terra pelo caminho da raiz, na vossa cabeça vai aparecer a castanha antiga, mãe escondida desse pau de cajus que derrubaram a filha enterrada doutro pau. Nessa hora o trabalho tem de ser o mesmo: derrubar outro cajueiro e outro e outro... É assim o fio da vida. Mas as pessoas que lhe vivem não podem ainda fugir sempre para trás, derrubando os cajueiros todos; nem correr sempre muito já na frente, fazendo nascer mais paus de cajus. É preciso dizer um princípio que se escolhe: costuma se começar, para 
ser mais fácil, na raiz dos paus, na raiz das coisas, na raiz dos casos, das conversas (VIEIRA, 2006, p. 60-61).

A identidade constrói-se, parece afirmar Luandino Vieira, reconhecendo a própria tradição e transmitindo os valores que dela derivam, assegurando assim a força primigênia da raiz, o quid último que funda o pensamento e o imaginário das pessoas em uma mítica conscientização da realidade.

A disputa pela posse de um ovo é o núcleo temático da última narrativa de Luuanda, "Estória da galinha e do ovo". Por meio da re-proposição de intensos diálogos, de sabor híbrido, entre um realismo de marca quase cinematográfico e a atmosfera proverbial e alegórica da reivindicação do ovo, Luandino Vieira propõe uma solução impossível, com a entrada em cena de duas crianças, Xico e Beto (outra marca rosiana na escrita do narrador angolano) que outorgam esperança e um final feliz à estória, e por extensão, o poderiam oferecer também para a terra de Angola. O final do relato é simbolicamente anunciador de boas notícias e da renovação da vida:

De ovo na mão, Bina sorria. O vento veio devagar e, cheio de cuidados e amizade, soprou-lhe o vestido gasto contra o corpo novo. Mergulhando no mar, o sol punha pequenas escamas vermelhas lá embaixo nas ondas mansas da Baía. Diante de toda a gente e nos olhos admirados e monandengues de miúdo Xico, a barriga redonda e rija de nga Bina, debaixo do vestido, parecia era um ovo grande, grande... (VIEIRA, 2005, p. 132).

Luandino Vieira marca, de maneira enérgica, também a escrita de Mia Couto, como ele mesmo declara em uma entrevista: "o primeiro contato que eu tenho com alguém que escreve um português que é arrevesado, que está misturado com a terra [...]. Foi o primeiro sinal da autorização de como eu queria fazer. Eu sabia que eu queria fazer isso, mas eu precisava de uma credencial do mais velho que disse 'esse caminho é abençoado"” (FELINTO, 2007). É a recriação de uma linguagem "abensonhada" que exemplifica a grandeza literária de Mia Couto, assim como para Luandino Vieira e outros autores lusófonos. Sempre na milagrosa linha rosiana de uma (re)imaginação estético-linguística da realidade, Mia Couto adota a "brincriação" (COUTO, 2007, p. 10) como sustento e fundamento da própria poética. Seu jogo narrativo afirma-se, particularmente, na reflexão metaliterária e na paródia como escamotage preferido para o desvendamento da estreiteza e da violência do pensamento colonial e para a rescrita ficcional de um universo onírico e fabular. A varanda do frangipani, por exemplo, se apresenta, como uma paródia do romance policial; as entrevistas tecem a teia de $O$ último voo do flamingo; Terra sonâmbula cria seu enredo a partir de cartas ou diários encontrados em um ônibus militar; $O$ outro pé da sereia reescreve a história de Moçambique em um entrelaçamento temporal que reinventa mapas geográficos e políticos. Em $A$ varanda do frangipani, a paródia do gênero policial não é o único recurso que Mia Couto utiliza; o eu narrador, Ermelindo Mucanga, apresenta-se como "póstumo", como o contador de uma história após a morte, como um novo irônico Brás Cubas. O fantasma de Ermelindo entra no corpo do inspetor Izidine, porque ele vai logo morrer e o xipoco (o espectro) poderá reassumir o lugar que lhe pertence, o reino dos mortos. A dupla fantasma-inspetor registra os fatos, os diálogos e os motivos que levaram todos (pelo menos, intencionalmente) a matar o cruel mulato, diretor de um asilo. Mortos e velhos, como em uma ciranda pirandelliana, confundem-se, perdem-se nos meandros da memória e da história e trocam as identidades. $\mathrm{O}$ fantasma registra, no 
papel de inspetor, uma "estória" que pretende salvar o povo moçambicano do esquecimento das tradições. Se o português que os velhos falam já não é mais a língua portuguesa, mas um idioma outro, recriado, reformulado por meio de símbolos e mitos da tradição africana, ("me educaram em língua que não me era materna", reconhece o xipoco), então o inspetor fantasma alegoriza o papel do escritor que, dos ossos e das aberrações mortíferas, recupera um discurso florescente em que ética e ideologia se mesclam com o perfume lírico da árvore do frangipani, dominador das páginas do xipoco e de Mia Couto. A alegoria que preenche a visão poética do narrador moçambicano se faz ainda mais evidente na citação de abertura do texto miacoutiano, ao registrar as palavras de Eduardo Lourenço, conforme o qual o Moçambique é uma gigantesca varanda sobre o Índico. Contudo, trata-se de uma varanda que é também "terra sonâmbula", espaço ambíguo e misterioso e, ao mesmo tempo, beco desesperado e obscuro. Uma varanda, herdeira do sertão rosiano, linguisticamente, e do sertão cabralino, eticamente.

A narrativa miacoutiana preocupa-se em reconstruir as ruínas de uma identidade moçambicana ainda disforme, desfigurada: Terra sonâmbula representa, ao nosso ver, o ponto mais alto da estética do autor da $A$ varanda do frangipani. Para Mia Couto, o problema da identidade nacional e, portanto, do sujeito que habita nela, ultrapassa a região do mito. De fato, reduzir a problemática da busca da identidade a uma noção puramente folclórica constitui um perigo de leitura e interpretação da alteridade. Em uma entrevista recente, Mia Couto discute o conceito de africanidade ao qual estamos habituados: mais além de uma folclorização da identidade, ocupar-se de literatura africana significa, sobretudo, revalorizar certas temáticas antropológicas, esquecidas no frenesi do bem-estar globalizado, tratar problemas éticos, explorar renovadas tendências linguísticas. Em lugar de uma literatura panfletária e ideológica, Mia Couto responde que é necessário "fazer" literatura. No trilho de Guimarães Rosa, ele reafirma a superioridade da ideia da poesia, irredutível a um gênero literário, nem a um processo de criação ou inspiração. Se a dicotomia e o binarismo da cultura cartesiana têm que ser rejeitados é porque, afirma Mia Couto, "há na poesia um saber para outras coisas essenciais que ficam à margem de uma sabedoria muito masculinizada e funcional que resulta das aplicações dos chamados métodos científicos. A apropriação dessa realidade intangível, dessa verdade que não cabe na frase feita, é esse o terreno da poesia" (COUTO, 2007, p. 5).

Nesse sentido, a amizade entre o velho Tuahir e o menino Muidinga, "caminheiros [...] murchos e desesperançados", na 'paisagem mestiça' de Terra sonâmbula, representa um dos vértices de poesia alcançado por Mia Couto. "O que faz andar a estrada é o sonho", declara a sabedoria de Tuahir (COUTO, 2007, p. 5). É uma estrada sozinha, pronta a desflorir. Porém, na descoberta do diário de Kindzu, é a literatura que manifesta seu poder sedutor, seu encanto de palavras que permanecem graves, lapidárias e esculpidas na eternidade. Os episódios de Junhito, o filho caçula metamorfoseado em galinha, até esquecer a linguagem dos homens, e de Farida, castigada desde a nascença por ser gêmea, não constituem apenas a retomada folclórica ou antropológica de mitos e tabus de uma sociedade muito distante das hegemônicas, mas perturbam o leitor pela capacidade do escritor, nova Sheerazade, descobrir, por trás do mito, os desejos de liberdade e a angústia da solidão, o prazer do interdito e a possibilidade de criar soluções, ou seja, relatar, pelo menos, ficções.

Há um episódio paradigmático no começo de Terra sonâmbula. Kindzu liga-se 
pela amizade com um indiano, Surendra Valá, que será obrigado a se exilar por causa de preconceitos raciais. Surendra convida o menino moçambicano a refletir sobre o fato deles serem "não indianos, mas índicos": "nós, os da costa, éramos habitantes não de um continente, mas de um oceano. Eu e Surendra partilhávamos a mesma pátria: o Índico" (COUTO, 2007, p. 25). A pátria não é reduzível a quatro fronteiras ("quero frátria, não pátria", canta Caetano Veloso). Pátria é, conforme as palavras de Kindzu, o espaço onde se desenrolam os fios comuns das histórias culturais individuais: "com o indiano minha alma arriscava se mulatar nos sentimentos de Surendra, aprendiz de um novo coração" (COUTO, 2007, p. 25). Esse novo conceito de mestiçagem, que mistura, sem medo o coração com a contemplação do mar e com o flutuar constante das fronteiras, até uma região ilimitada, sem perímetros, "horizontal" (onde o olhar se perde no horizonte) constitui a possibilidade de não se conceber sem laços, sem raízes, mas de se pensar dentro de uma experiência de comunhão, de fraternidade real que deveria ser o rosto do verdadeiro multiculturalismo. Nesse sentido, o feiticeiro revela que "o problema não é o lugar, mas o caminho" (COUTO, 2007, p. 31). O caminho exalta os processos de vitalidade, de luta contra a morte, os delírios, as doenças: "ele falava de uma viagem cujo único destino era o desejo de partir novamente" (COUTO, 2007, p. 31). E se a viagem mata "as certezas da infância" (COUTO, 2007, p. 33), outras viagens podem se reabrir a uma "palavra azul" (COUTO, 2007, p. 41) que faça estremecer e regressar a um prantochão de criança.

Mia Couto desconstrói os clichês da africanidade, em particular, a realidade do passado colonial e de seus vestígios, concentrando-se nos dinamismos que fazem da África o continente ainda mais inexplorado. Os estereótipos da cultura africana lusófona indicam o caminho também para a prática da literatura comparada. O lugar-comum nem sempre possui, nas trocas culturais que a literatura comparada promove, uma conotação exclusivamente negativa. Ele procede, na realidade, como arma de dois gumes: se, por um lado, o lugar-comum se reduz a globalizar e a despersonalizar, desidentificar materiais nacionais, cuja diversidade perde-se em um aglomerado indistinto de banalidades, pelo outro, ele funciona como sistêmico aparato de diferença e originalidade, até necessário, porque ele valida a abertura de fronteiras e a dinâmica do conhecimento cultural.

$* \quad *$

A literatura comparada contribui para que se pense em um reajuste da geografia da literatura, do espaço que se outorga à identidade, e da hipótese de resposta que se vislumbra. O comparatismo observa o fato literário em uma perspectiva de flexibilidade. Não podem existir (somente) normas rígidas, leis fixas e imóveis. Pelo contrário, para o comparatismo a literatura dever ser lida, interpretada e considerada como um constante ultrapassar limites e fronteiras, uma transgressão infinita, uma ultrapassagem porque o texto literário apresenta-se como lugar de trânsito. Nessa transitoriedade, que faz a diferença da metodologia comparativista, não se trata de relegar o texto artístico para uma simples explicação, mas de procurar, parafraseando o título de Goethe, as afinidades eletivas para que elas funcionem como elementos e pontos de conexão ou de desdobramentos. Essas afinidades sugerem, indicam, não explicam, fechando assim o círculo da produção e da recepção da mensagem. As afinidades realizam, ao contrário, um acréscimo produtivo, que dilata a interpretação do texto e as imagens que nesse se 
produzem. Insistir, por exemplo, na literatura nacional, hoje, seria invalidar o processo de leitura da atualidade que vê na literatura um espaço de relações estéticas e filosóficas que, retomando um conceito caro a Pascale Casanova (A república mundial das letras, de 2002), viabilizam a mediação. São relações de "dom e troca", porque realizados graças ao efeito da intersemiose. Nessa reciprocidade, sempre profícua, onde não há predominância de um campo sobre o outro, o diferente faz a diferença (o diferencial) da literatura. Porém, para esse reajuste, precisa-se de uma "educação", a partir do nível de ensino escolar básico até o ensino universitário, e a primeira educação é tarefa dos professores, dos pesquisadores e, enfim, dos leitores. A literatura comparada pode ser considerada como um discurso privilegiado de inclusão, mediação, viabilização e educação. Sendo ela um lugar de revitalizações, a literatura comparada se concede a quem não aceita as determinações estancadas que fazem da literatura um discurso estético elitista. Na época romântica, se reprochava ao escritor seu isolamento em uma torre de marfim. Hoje a literatura situa-se, infelizmente, na mesma ubiquação. É hora de fazer do comparatismo o método de leitura de uma literatura adequada ao devir e às transformações da atualidade. A tarefa está nas mãos da comunidade de leitores e pesquisadores, comunidade não imaginária (como sugeria há alguns anos Benedict Anderson), mas historicamente e geograficamente transfigurada.

Nos novos modelos de comparatismo global, a geopolítica faz da literatura um espaço de discussão fundamental, onde a francofonia, por exemplo, pode não apenas designar as relações transnacionais entre a França e suas ex-colônias, mas aquelas outras zonas de contato linguístico em todo o mundo onde o francês, ou algum tipo de francês, é um dos muitos idiomas em uso. Tratar-se-ia de uma experiência que marca uma abertura para com o mundo cultural holandês, espanhol, belga, japonês, italiano e turco, entre outros, todos vinculados à problemática da emigração.

Assim, a literatura comparada assume o papel de depósito de pensamentos e de memórias, em que se rediscute a tradição como valor iniludível de conhecimento e produção de outro conhecimento, atualizado. Nessa "mobilidade" que a tradição defende como única possibilidade para os trânsitos epistemológicos, a memória de um povo se torna uma memória "impessoal", no sentido de que corresponde a qualquer sujeito que vive a experiência da memória. A memória de Moçambique é a memória de Mia Couto e dos anciões, depositários dessa consciência, sem dúvida, mas representa, ao mesmo tempo, a memória de todos aqueles povos que ainda não são relatados na escrita ambígua e duradoura da ficção. Essa memória fala todas as línguas das comunidades, imaginadas e reais e recompõe os fragmentos, que seriam estragados, em falares e escritos em busca de um sentido, de uma experiência vivida redentora. Com razão, Tania Franco Carvalhal pode afirmar, em um capítulo brilhante sobre a intertextualidade:

Na noção do literário como globalidade estão presentes a de "comunidade" e a de "continuidade", sendo esta entendida como um processo que alterna memória e esquecimento. Vigora também aí, de forma subjacente, a perda do conceito de propriedade privada, pois nesse grande conjunto tudo se torna propriedade de todos, patrimônio comum a que os escritores recorrem consciente ou inconscientemente. A tradição se faz por um efeito de memória (CARVALHAL, 2003, p. 71).

A literatura comparada reinventa assim o mapa da história e da geografia 
literária. Em uma época que se destaca por elucubrações intelectuais, o comparatismo pode aspirar a uma Weltliteratur, em que a utopia do discurso se une ao vigor do reajuste geopolítico e cultural que faz das humanidades não um espaço em crise, mas um lugar de debate.

\section{BIBLIOGRAFIA}

ABDALA, Benjamin. De voos e ilhas. São Paulo: Ateliê editorial, 2003.

AGUALUSA, José Eduardo. Viagem pela fronteira do sonho. Entrevista a Ubiratan Brasil. Estado de São Paulo, 12 de maio de 2007, p. 3.

CARVALHAL, Tania Franco. O próprio e o alheio. São Leopoldo: Unisinos, 2003.

CASANOVA, Pascale. A república mundial das letras. São Paulo: Estação Liberdade, 2002.

COUTO, Mia. Terra sonâmbula. São Paulo: Companhia das Letras, 2007.

Histórias com alma. Entrevista a Ubiratan Brasil. Estado de São Paulo. Caderno

2, sáb. 16 de junho de 2007, ano XXI, n. 7, p. 1-5.

DERRIDA, Jacques. Mal de archivo. Madrid: Trotta, 1997.

FELINTO, Marilene. Mia Couto e o exercício da humildade. Disponível em: http://www.macua.org/miacouto/MiaCoutoexerciciodahumildade.htm. Acesso em: $1^{\mathrm{o}} \mathrm{de}$ junho de 2007.

HANSEN, João Adolfo. $O$ ó: a ficção da literatura em Grande sertão: veredas. São Paulo: Hedra, 2000.

LABAN, Michel et alli. Luandino: José Luandino Vieira e a sua obra. Lisboa: Edições 70, 1980.

LIMA, Luiz Costa. Mito e provérbio em Guimarães Rosa. Colóquio Letras. Lisboa, nº 17, jan. 1974.

MARQUEZINI, Fabiana Carelli. Ruínas de mitos, sementes de sonhos: ditos e provérbios em Guimarães Rosa e Luandino Vieira. Via Atlântica. São Paulo, n. 9/2006, p. 45-61.

MATA, Inocência. A condição pós-colonial das literaturas africanas de língua portuguesa. In: LEÃO, Ângela Vaz (org.). Contatos e ressonâncias: literaturas africanas de língua portuguesa. Belo Horizonte: PUC-Minas, 2003. p. 43-72.

PADILHA, Laura. Poesia angolana e remapeamento etno-cultural: trajetos. In: JOBIM, José Luis, Lívia Reis, et al. (Orgs.). Sentidos dos lugares. Rio de Janeiro: ABRALIC, 2005. p. 83-95.

PIRES LARANJEIRA, José Luis. Mia Couto e as literaturas de língua portuguesa. Revista de Filología Románica. Anejos, 2001, II: p. 185-205.

TODOROV, Tzvetan. Introdução à literatura fantástica. São Paulo: Perspectiva, 2004.

VIEIRA, Luandino. Luuanda. São Paulo: Companhia das Letras, 2006.

WELLEK, René. Conceitos da crítica. São Paulo: Cultrix, [s.d.]. 